\title{
INCREASING THE EFFICIENCY OF SURFACE IRRIGATION BY USING SURGE IRRIGATION FOR COTTON PRODUCTION IN THE DELTA SOILS
}

\author{
El-D. El-D. Deshish(1) and A.M. Okacha(2) \\ (1) Cotton Research Institute, Agricultural Research Center, Giza, Egypt \\ (2) Eng. Dept., Faculty of Agriculture, Kafr El-Sheikh University
}

Received: Apr. 4, 2021

Accepted: Apr. 19, 2021

\begin{abstract}
Two field experiments were conduct at Sakha Agricultural Research Station at Kafr El-Sheikh Governorate, Egypt, during 2018 and 2019 seasons to study increasing the efficiency of surface irrigation by using surge irrigation for cotton production in the Delta soils for Giza 96 cotton variety. A split plots design with four replications was used, where the main plots involved three lengths of irrigation rows $(30$, 40 and 50 meter) and the sub plots included three surge irrigation timing systems (time for opening and closing surge irrigation) (10 minute open -10 minute close, 15 minute open -15 minute close and 20 minute open -20 minute close until finish from irrigation). The results indicated that; The $\mathbf{3 0}$ meter row length irrigation significantly increased plant height, no. of fruiting branches/plant, number of open bolls /plant, boll weight, seed cotton yield/plant and seed cotton yield/fed. compared with the other treatments irrigation row lengths $\mathbf{4 0}$ and $\mathbf{5 0}$ meter. The surge irrigation timing system $\mathbf{1 0}$ minutes open and 10 minutes close significantly increased plant height, number of fruiting branches/plant, number of open bolls/plant, boll weight, seed cotton yield/plant and seed cotton yield/fed. compared with the other surge irrigation timing systems (15-15 and 2020). The interaction between 30 meter row length and surge irrigation timing system 10 minutes open and 10 minutes close gave the good values of growth, yield and its components of Giza 96 cotton variety in both seasons. Row lengths irrigation and surge irrigation timing systems treatments and its interaction did not exhibit any significant effect on seed index, lint \% and fiber properties in both seasons. Finally, using $\mathbf{3 0}$ meter irrigation row length and surge irrigation timing systems 10 minutes open and 10 minutes close gave the highest seed cotton yield/fed. for Giza 96 cotton cultivar under the conditions of Kafr El-Sheikh in the Delta soils.
\end{abstract}

Key words: Cotton, Irrigation, Surge irrigation, Growth, Yield and yield components and Fiber properties.

\section{INTRODUCTION}

Water is the most limiting factor for plant production in arid and semiarid regions, and when the source of water is limited, the demand for water increases and water management will become an essential practice used by farmers. Irrigation among cultural practices and is the most important input ensuring high and good quality cotton production. Although cotton known to be drought tolerant, its yield could significantly be increased with appropriate irrigation management (Tekinel and Kanber, 1989). While excessive irrigation could promote vegetative growth and decrease yield, inadequate and infrequent irrigation can increase shedding ratio. Cotton production in regions depends on managed irrigation systems for optimum yield (Steger et al., 1998). Turner et al. (1986) found that water stress early in the season could affect the subsequent growth and development of cotton. Bonner (1993) showed that when 
irrigation is delayed a few days beyond the actual need, the impact can often be adverse to yield and earliness. However, other studies, namely Bange and Milroy (2000), demonstrated that cotton plants under full irrigation experienced increased vegetative growth, delayed maturity and reduced number of open bolls. Ertek and Kanber (2003) reported that cotton yield, boll number and lint percentage increased linearly with irrigation water amount. Mert (2005) reported that water stress reduced some cotton yield components in the Amik Plain. Similar results were reported by, Aujla et al. (2004), Jalota et al. (2006) and Chun-yan et al, (2007). One of the critical problems in cotton production is the amount of irrigation. Excessive irrigation of cotton can lead to increase in vegetative growth, delay maturity, reduce no. of open bolls, and decrease the yield. Whereas, insufficient water can cause an increase in shedding, thus, a decrease in yield (Karam, et al., 2006; Buttar, et al., 2007 and Detar, 2008) and the intensity of the operation requires that soil water supply is kept at the optimal level to maximize yield (Sezan, et al., 2008). There have been many recent innovations in estimating crop water requirements of cotton. Most of them involve a system management based on irrigation scheduling upon crop water requirements and potential evapotranspiration (Morrow and Krieg, 1990). Deshish, et al. (2015a).Electronic gates irrigation significantly increased plant height, number of fruiting branches/plant, number of open bolls per plant, boll weight, seed index and seed cotton yield and gave the good fiber properties compared with the other irrigation systems furrow irrigation and normal gates irrigation. Deshish, et al. (2015b) found that using improvement irrigation method saved about 4.88 and $8.50 \%$ for surge and alternative irrigation compared with traditional furrow irrigation method. The different surface irrigation systems had significant effect on growth, yield and yield components. The alternative irrigation system gave the highest values of number of fruiting branches /plant, number of open bolls /plant, boll weight, seed index and seed cotton yield /fed. Khalifa, et al. (2014) reported that irrigation methods (drip, gated pipe and furrow irrigation had significant effect on growth, yield and yield components. The gated pipe irrigation method significantly increased number of fruiting branches/plant, boll weight, number of open bolls/plant and seed cotton yield/fed. The objective of this research was to study the increasing the efficiency of surface irrigation by using surge irrigation for cotton production in the Delta soils for Giza 96 cotton variety.

\section{MATERIALS AND METHODS}

Two field experiments were conduct at Sakha Agricultural Research Station at Kafr El-Sheikh Governorate, Egypt, during 2018 and 2019 seasons to study increasing the efficiency of surface irrigation by using surge irrigation for cotton production in the Delta soils for Giza 96 cotton variety. Characterized Giza 96 variety showed in Table (1). A split plots design with four replications was used, where the main plots involved three lengths of planting rows $(30,40$ and 50 meter length) and the sub plots included three surge irrigation timing systems time for opening and closing surge irrigation (10 minute open -10 minute close (10-10), 15 minute open -15 minute close (15-15) and 20 minute open -20 minute close (20-20) until finish from irrigation).

Cotton seeds were planted early on the first week of April after two cuts of (Trifolium alexandrinum, L.) in 2018 and 2019 seasons. The sub-plots size including six rows with lengths tested 
under study in both seasons. In all experiments the phosphorus fertilizer as ordinary superphosphate (15.5\% P2O5) at the rate of $22.5 \mathrm{~kg} \mathrm{P2O5/fed.} \mathrm{was}$ incorporated during seed bed preparation. Nitrogen fertilizer in the form of ammonium nitrate $(33.5 \% \mathrm{~N})$ at the rate of $60 \mathrm{~kg} \mathrm{~N} / \mathrm{fed}$. were applied in two equal doses, immediately before the first and the second irrigations. Potassium fertilizer in the form of potassium sulfate (48 \% K2O) at the rate of $24 \mathrm{~kg} \mathrm{K2O} / \mathrm{fed}$. was side-dressed in a single dose before the second irrigation. Standard agricultural practices were followed throughout the growing seasons.

All samples were taken at random in order to study the traits. At harvest, 6 guarded plants were randomly taken from the central row of each plot to determine Growth characters; (Plant height, First fruiting node, No. of fruiting branches/plant). Yield and yield components; (No. of open bolls/plant, boll weight, seed cotton yield/plant, lint $\%$, seed index and seed cotton yield (ken./fed.) was estimated as the weight of seed cotton yield by kilogram picked from the four middle rows in sub plot collected from two picks, then converted to yield/fedden in kentar (Kentar $=157.5$ kg.). Fiber properties; (Fiber length and uniformity index, fiber strength and Micronaire reading) Samples of lint cotton under different treatments were tested at the laboratories of the Cotton Technology Research Division, Cotton Research Institute in Giza to determine fiber properties, under controlled conditions of $65 \% \pm 2$ of relative humidity and $21^{\circ} \pm 2$ Co temperature. Were determined on digital Fibrograph instrument 630, Pressley instrument and Micronaire instrument 675 respectively, according to A.S.T.M. (2012) at the C.R.I. laboratories. Analysis of variance of the obtained data of each season was performed. The measured variables were analysed by ANOVA using $M$ Stat-C statistical package (Freed, 1991). Mean comparisons were done using least significant differences (L.S.D) method at $5 \%$ level $(P \leq 0.05)$ of probability to compare differences between the means (Snedecor and Cochran, 1989).

Table 1. Characterized the Giza 96 variety.

\begin{tabular}{cl}
\hline \multicolumn{1}{c}{ Genotype } & Giza 96 \\
\hline $\begin{array}{c}\text { Species } \\
\text { Category }\end{array}$ & $\begin{array}{l}\text { Barbadense. } \\
\text { Extra-long staple and extra fine. }\end{array}$ \\
\hline Characteristics & $\begin{array}{l}\text { Extra-long staple variety characterized by high yielding, earliness, } \\
\text { resistance to fusarium wilt, high lint percentage (\%) about } 38 \% .\end{array}$ \\
\hline & $\begin{array}{l}\text { The stem has a length with resistance to lodging and has a green color } \\
\text { mixed by dim red with internodes length ranged from short to medium. }\end{array}$ \\
$\begin{array}{c}\text { The leaves have navicular shape; medium size with medium lobes and } \\
\text { distinguishing } \\
\text { Characters }\end{array}$ & $\begin{array}{l}\text { leather feel. The node of the first fruiting branch ranged from } 7-8, \text { the } \\
\text { axillaries buds will activate to give a fruiting branch, which ended with } \\
\text { one or two bolls. Flower petals has shape like a tubular, the petals is } \\
\text { rolling. The boll shape is conical shape with shoulder and many glands. } \\
\text { Seed is medium-sized, the fuzz cover about } 1 / 4 \text { to } 1 / 2 \text { from the whole size, } \\
\text { and fuzz color is gray-greenish. }\end{array}$ \\
\hline
\end{tabular}

Hybrid bred by Breeding Res. Section, Cotton Res. Inst., Agric. Res. Center, Giza, Egypt. 


\section{RESULTS AND DISCUSSION}

The effect of row length, surge irrigation timing systems (time for opening and closing surge irrigation) and the interaction between them on growth character, yield and its components and fiber properties of Giza 96 cotton variety during 2018 and 2019 seasons were shown in Tables (2, 3, 4, 5, 6 and 7).

\section{1- Effect of row length on growth character, yield and its components and fiber properties of cotton:}

The data in Table (2) showed that cotton growth traits (Plant height and no. of fruiting branches/plant) were significantly affected by the row length irrigation in both seasons. The $30 \mathrm{~m}$ row length irrigation significantly increased plant height and no. of fruiting branches/plant compared with the other treatments (40 and $50 \mathrm{~m}$ length), while significantly decreased first fruiting node in both seasons Table (2). Data also in Table (4) showed that yield and yield components were significantly affected by the row length irrigation in both seasons. The rows with length $30 \mathrm{~m}$ significantly increased number of bolls /plant, boll weight, seed cotton yield/plant and seed cotton yield/fed. compared with the other treatments while, did not exhibit any significant effect on seed index and lint \% in both seasons. The increasing in growth and yield by using the $\mathbf{3 0}$ meter irrigation row length may be due to the good water supply to the cotton plant. Similar results were obtained by Ertek and Kanber (2003) reported that cotton yield, boll number and lint percentage increased linearly with irrigation water amount. The data in Table (6) showed that row length irrigation treatments did not exhibit a significant effect on all fiber properties in both seasons.
2- Effect of surge irrigation timing systems on growth character, yield and its components and fiber properties of cotton:

Data in Table (2) showed that cotton growth characters (plant height and no. of fruiting branches/plant) were significantly affected by the surge irrigation timing systems. The surge irrigation timing system 10 minutes open and 10 minutes close (10-10) significantly increased plant height and no. of fruiting branches/plant. While, did not exhibit any significant effect on first fruiting node in both seasons. Data in Table (4) showed that surge irrigation timing systems significant effect on number of open bolls/plant, boll weight, seed cotton yield/plant and seed cotton yield (ken./fed.).in both seasons. The surge irrigation timing system 10 minutes open and 10 minutes close (10-10) significantly increased no. of open bolls/plant, boll weight, seed cotton yield/plant and seed cotton yield (ken./fed.). These results may be to the improving in water requirements to cotton plants by using this system. Similar results were obtained by Deshish, et al. (2015b) The data showed that cotton fiber properties were insignificantly affect by the surge irrigation timing systems (time for opening and closing irrigation treatments) in 2018 and 2019 seasons Table (6).

\section{3- Effect of the interaction between} row length and surge irrigation timing systems on growth, yield and its components and fiber properties of cotton.

Data in Table (3) showed that the interaction between row length and surge irrigation timing system (time for opening and closing irrigation) insignificant effect on growth characters (Plant height and number of fruiting branches/plant) and first fruiting node of 
Giza 96 cotton variety in both seasons. The interaction between row length irrigation and surge irrigation timing systems significant effect on number of open bolls/plant, boll weight, seed cotton yield/plant and seed cotton yield/fed. while, insignificant effect on seed index and lint \% in both seasons Table (5). The interaction between $30 \mathrm{~m}$ row length and surge irrigation timing system 10-10 (10 minutes open and 10 minutes close) gave the good values of number of open bolls/plant, boll weight, seed cotton yield/plant and seed cotton yield/fed of Giza 96 cotton variety in both season compared with the other surge irrigation timing systems (15-15 and 20-20). Data in Table (7) showed that the interaction between row length and surge irrigation timing systems treatments did not exhibit any significant effect on fiber properties of Giza 96 cotton variety during 2018 and 2019 seasons.

Table 2: Effect of the row length and surge irrigation timing system on growth characters and first fruiting node of cotton during 2018 and 2019 seasons.

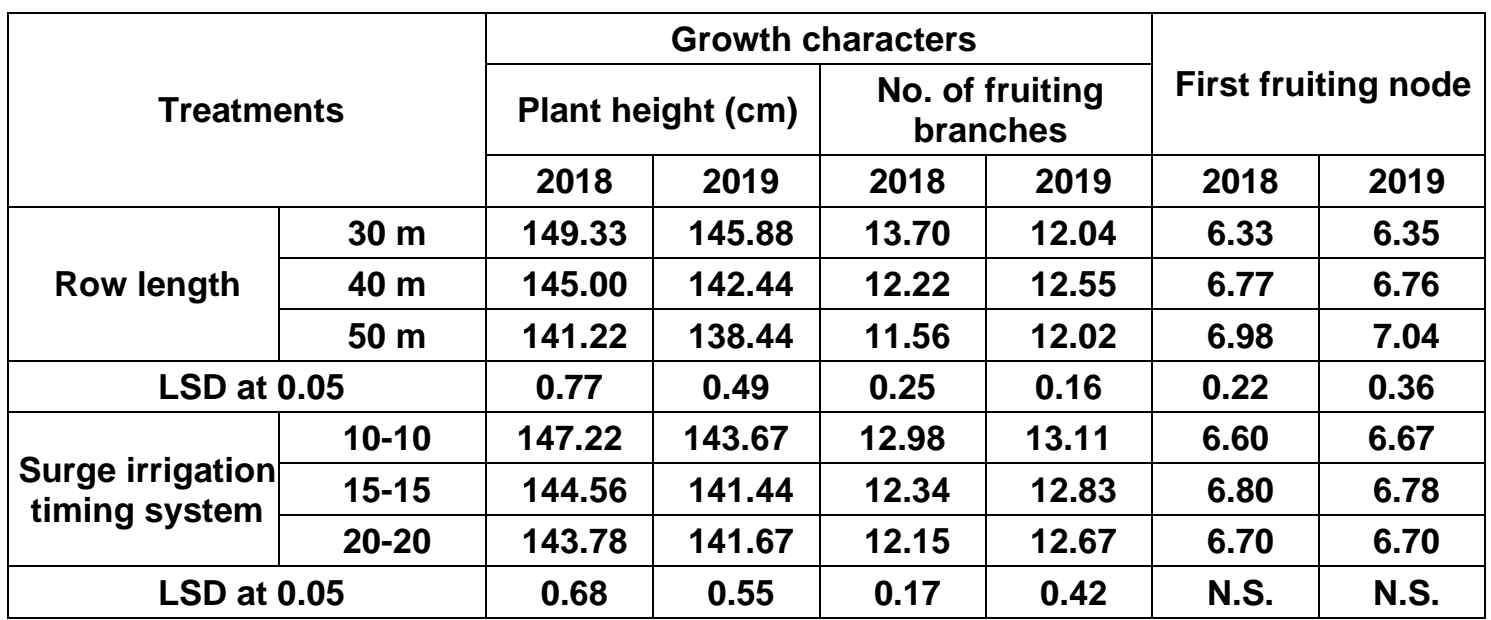

Table 3: Effect of the interaction between row length and surge irrigation timing system on growth characters and first fruiting node of cotton during 2018 and 2019 seasons.

\begin{tabular}{|c|c|c|c|c|c|c|c|}
\hline \multirow{2}{*}{\multicolumn{2}{|c|}{ Treatments }} & \multicolumn{4}{|c|}{ Growth characters } & \multirow{2}{*}{\multicolumn{2}{|c|}{ First fruiting node }} \\
\hline & & \multicolumn{2}{|c|}{ Plant height (cm) } & \multicolumn{2}{|c|}{$\begin{array}{c}\text { No. of fruiting } \\
\text { branches }\end{array}$} & & \\
\hline $\begin{array}{l}\text { Row } \\
\text { Length }\end{array}$ & $\begin{array}{l}\text { Surge irrigation } \\
\text { timing system }\end{array}$ & 2018 & 2019 & 2018 & 2019 & 2018 & 2019 \\
\hline \multirow{3}{*}{$30 \mathrm{~m}$} & $10-10$ & 154.00 & 147.0 & 2018 & 2019 & 6.23 & 6.30 \\
\hline & $15-15$ & 148.67 & 145.00 & 14.46 & 14.46 & 6.46 & 6.40 \\
\hline & $20-20$ & 145.33 & 145.66 & 13.40 & 13.93 & 6.30 & 6.36 \\
\hline \multirow{3}{*}{$40 \mathrm{~m}$} & $10-10$ & 146.67 & 145.00 & 13.23 & 13.73 & 6.60 & 6.66 \\
\hline & $15-15$ & 144.66 & 141.67 & 12.50 & 12.67 & 6.80 & 6.76 \\
\hline & $20-20$ & 143.67 & 140.66 & 12.23 & 12.60 & 6.93 & 6.86 \\
\hline \multirow{3}{*}{$50 \mathrm{~m}$} & $10-10$ & 141.00 & 139.00 & 11.93 & 12.40 & 6.96 & 7.07 \\
\hline & 15-15 & 140.33 & 137.66 & 12.00 & 12.20 & 7.13 & 7.20 \\
\hline & $20-20$ & 142.33 & 138.67 & 11.40 & 11.96 & 6.86 & 6.87 \\
\hline \multicolumn{2}{|c|}{ LSD at 0.05} & N.S. & N.S. & N.S. & N.S. & N.S. & N.S. \\
\hline
\end{tabular}


Table 4: Effect of the row length and surge irrigation timing system on yield and yield components of cotton during 2018 and 2019 seasons.

\begin{tabular}{|c|c|c|c|c|c|c|c|c|c|c|c|c|c|}
\hline \multirow{2}{*}{\multicolumn{2}{|c|}{ Treatments }} & \multicolumn{2}{|c|}{$\begin{array}{c}\begin{array}{c}\text { No. of open } \\
\text { bolls }\end{array} \\
\end{array}$} & \multicolumn{2}{|c|}{$\begin{array}{c}\text { Boll weight } \\
(\mathrm{g})\end{array}$} & \multicolumn{2}{|c|}{$\begin{array}{c}\text { Seed cotton } \\
\text { yield/plant }\end{array}$} & \multicolumn{2}{|c|}{$\begin{array}{c}\text { Seed index } \\
(\mathrm{g})\end{array}$} & \multicolumn{2}{|c|}{ Lint (\%) } & \multicolumn{2}{|c|}{$\begin{array}{l}\text { Seed cotton } \\
\text { yield/fed. }\end{array}$} \\
\hline & & 2018 & 2019 & 2018 & 2019 & 2018 & 2019 & 2018 & 2019 & 2018 & 2019 & 2018 & 2019 \\
\hline \multirow{3}{*}{$\begin{array}{l}\text { Row } \\
\text { length }\end{array}$} & $30 \mathrm{~m}$ & 23.31 & 24.05 & 217 & 2.52 & 57.87 & 60.72 & 10.35 & 10.36 & 39.57 & 39.57 & 8.82 & 8.91 \\
\hline & 11 & 98 & 21.82 & 2.01 & 2.08 & 24 & 45.59 & 10.15 & 10.25 & 39.58 & 39.60 & 8.07 & 8.21 \\
\hline & $50 \mathrm{~m}$ & 20.28 & 20.52 & 1.78 & 1.80 & 36.10 & 37.01 & 10.13 & 10.11 & 39.53 & 39.55 & 7.36 & 7.51 \\
\hline \multicolumn{2}{|c|}{ LSD at 0.05} & 0.97 & 0.88 & 0.32 & 0.15 & 0.95 & 0.84 & N.S. & N.S. & N.S. & $N S$ & 0.37 & 0.22 \\
\hline \multirow{3}{*}{$\begin{array}{c}\text { Surge } \\
\text { irrigation } \\
\text { timing } \\
\text { system }\end{array}$} & $10-10$ & 22.46 & 22.61 & 2.22 & 2.26 & 50.43 & 51.73 & 10.20 & 10.26 & 39.54 & 39.53 & 8.35 & 8.47 \\
\hline & $15-15$ & 21.77 & 22.22 & 2.07 & 2.13 & 45.53 & 47.73 & 10.27 & 10.24 & 39.57 & 39.59 & 8.08 & 8.21 \\
\hline & $20-20$ & 21.34 & 21.57 & 1.90 & 2.01 & 42.25 & 43.86 & 10.16 & $\mid 10.22$ & 39.57 & 39.60 & 7.82 & 1.94 \\
\hline \multicolumn{2}{|c|}{ LSD at 0.05} & 0.27 & 0.39 & 0.12 & 0.16 & 0.75 & 0.77 & N.S. & N.S. & N.S. & N.S. & 0.09 & 0.12 \\
\hline
\end{tabular}

Table 5: Effect of the interaction between row length and surge irrigation timing system on yield and yield components of cotton during 2018 and 2019 seasons.

\begin{tabular}{|c|c|c|c|c|c|c|c|c|c|c|c|c|c|}
\hline \multicolumn{2}{|c|}{ Treatments } & \multicolumn{2}{|c|}{\begin{tabular}{|c|}
$\begin{array}{c}\text { No. of open } \\
\text { bolls }\end{array}$ \\
\end{tabular}} & \multicolumn{2}{|c|}{$\begin{array}{l}\text { Boll weight } \\
\text { (g) }\end{array}$} & \multicolumn{2}{|c|}{$\begin{array}{c}\text { Seed cotton } \\
\text { yield/plant }\end{array}$} & \multicolumn{2}{|c|}{$\begin{array}{c}\text { Seed index } \\
\text { (g) }\end{array}$} & \multicolumn{2}{|c|}{ Lint (\%) } & \multicolumn{2}{|c|}{$\begin{array}{c}\text { Seed cotton } \\
\text { yield/fed. }\end{array}$} \\
\hline $\begin{array}{c}\text { Row } \\
\text { length }\end{array}$ & \begin{tabular}{|r} 
Sur \\
irriga \\
timi \\
syst
\end{tabular} & & & & & & 9 & & & 8 & 19 & 18 & 19 \\
\hline \multirow{3}{*}{$30 \mathrm{~m}$} & & & & & & 11 & 66.43 & & 10.38 & 39.55 & 39.52 & 13 & \\
\hline & 15 & 23.10 & 23.90 & 40 & 2.46 & 5.43 & 58.94 & 10.52 & 10.36 & 39.59 & 39.59 & 30 & \\
\hline & & 3 & 23.67 & & & 2.08 & 56.80 & 26 & 35 & 39.58 & 3 & 3 & \\
\hline \multirow{3}{*}{$40 \mathrm{~m}$} & & 3 & 22.20 & & & 89 & 48.77 & 10.17 & 10.26 & 39.54 & 39.54 & 8.30 & 8. \\
\hline & 1 & 21.93 & 21.86 & 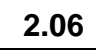 & 2.13 & 5.31 & 46.62 & 10.15 & 10.26 & 39 & 39.63 & 8.06 & \\
\hline & & 2 & & & & 0.52 & 41.38 & 12 & 10.23 & 39.61 & \begin{tabular}{|l|}
39.64 \\
\end{tabular} & 36 & \\
\hline \multirow{3}{*}{$50 \mathrm{~m}$} & & 0.86 & 21.03 & 1.8 & 1.90 & 3.31 & \begin{tabular}{|l|}
39.98 \\
\end{tabular} & 10.16 & 10.14 & 39.53 & 39.54 & 7.63 & 7.73 \\
\hline & $15-15$ & 20.30 & 20.90 & 1.76 & 1.80 & 35.86 & 37.62 & 10.13 & 10.10 & 39.54 & 39.55 & 40 & 7.50 \\
\hline & $20-20$ & \begin{tabular}{|l|}
19.70 \\
\end{tabular} & 19.63 & & & 34.15 & 33.41 & 10.11 & 10.09 & 39.53 & 39.56 & 06 & 7. \\
\hline \multicolumn{2}{|c|}{ SD at 0.05} & 0.4 & 0.52 & 0.4 & 0.3 & & 0.78 & N.S. & N.S. & N.S. & N.S. & 0.27 & 0.15 \\
\hline
\end{tabular}

Table 6: Effect of the row length and surge irrigation timing system on fiber properties of cotton during 2018 and 2019 seasons.

\begin{tabular}{|c|c|c|c|c|c|c|c|c|c|}
\hline \multirow{2}{*}{\multicolumn{2}{|c|}{ Treatments }} & \multicolumn{2}{|c|}{ Fiber length } & \multicolumn{2}{|c|}{ Uniformity index } & \multicolumn{2}{|c|}{$\begin{array}{l}\text { Fiber strength } \\
(\mathrm{g} / \mathrm{tex} .)\end{array}$} & \multicolumn{2}{|c|}{$\begin{array}{l}\text { Micronaire } \\
\text { reading }\end{array}$} \\
\hline & & 2018 & 2019 & 2018 & 2019 & 2018 & 2019 & 2018 & 2019 \\
\hline \multirow{3}{*}{$\begin{array}{l}\text { Row } \\
\text { Length }\end{array}$} & $30 \mathrm{~m}$ & 35.36 & 35.37 & 86.4 & 86.4 & 10.67 & 10.65 & 4.20 & 4.16 \\
\hline & $40 \mathrm{~m}$ & 35.41 & 35.55 & 86.5 & 86.3 & 10.64 & 10.58 & 4.18 & 4.16 \\
\hline & $50 \mathrm{~m}$ & 35.32 & 35.39 & 86.1 & 86.4 & 10.56 & 10.45 & 4.17 & 4.20 \\
\hline \multicolumn{2}{|c|}{ LSD at 0.05} & N.S. & N.S. & N.S. & N.S. & N.S. & N.S. & N.S. & N.S. \\
\hline \multirow{3}{*}{$\begin{array}{c}\text { Surge } \\
\text { irrigation } \\
\text { timing system }\end{array}$} & $10-10$ & 35.35 & 35.38 & 86.2 & 86.4 & 10.56 & 10.53 & 4.17 & 4.16 \\
\hline & $15-15$ & 35.29 & 35.49 & 86.4 & 86.5 & 10.67 & 10.55 & 4.21 & 4.18 \\
\hline & $20-20$ & 35.44 & 35.43 & 86.4 & 86.3 & 10.63 & 10.61 & 4.16 & 4.19 \\
\hline \multicolumn{2}{|c|}{ LSD at 0.05} & N.S. & N.S. & N.S. & N.S. & N.S. & N.S. & N.S. & N.S. \\
\hline
\end{tabular}


Increasing the efficiency of surface irrigation by using surge irrigation for

Table 7: Effect of the interaction between row length and surge irrigation timing system on fiber properties of cotton during 2018 and 2019 seasons.

\begin{tabular}{|c|c|c|c|c|c|c|c|c|c|}
\hline \multicolumn{2}{|c|}{ Treatments } & \multicolumn{2}{|c|}{ Fiber length } & \multicolumn{2}{c|}{ Uniformity index } & $\begin{array}{c}\text { Fiber strength } \\
\text { (g/tex.) }\end{array}$ & \multicolumn{2}{c|}{$\begin{array}{c}\text { Micronaire } \\
\text { reading }\end{array}$} \\
\hline $\begin{array}{c}\text { Row } \\
\text { length }\end{array}$ & $\begin{array}{c}\text { Surge } \\
\text { irrigation } \\
\text { timing } \\
\text { system }\end{array}$ & 2018 & 2019 & 2018 & 2019 & 2018 & 2019 & 2018 & 2019 \\
\hline \multirow{4}{*}{$30 \mathrm{~m}$} & $10-10$ & 35.40 & 35.50 & 86.0 & 86.4 & 10.48 & 10.66 & 4.16 & 4.15 \\
\cline { 2 - 11 } & $15-15$ & 35.32 & 35.33 & 86.6 & 86.3 & 10.75 & 10.63 & 4.23 & 4.16 \\
\cline { 2 - 11 } & $20-20$ & 35.37 & 35.27 & 86.4 & 86.6 & 10.78 & 10.67 & 4.21 & 4.19 \\
\hline \multirow{4}{*}{$40 \mathrm{~m}$} & $10-10$ & 35.29 & 35.48 & 86.7 & 86.7 & 10.69 & 10.54 & 4.18 & 4.16 \\
\cline { 2 - 11 } & $15-15$ & 35.33 & 35.54 & 86.5 & 86.6 & 10.74 & 10.55 & 4.22 & 4.19 \\
\cline { 2 - 10 } & $20-20$ & 35.62 & 35.64 & 86.4 & 85.9 & 10.48 & 10.67 & 4.15 & 4.14 \\
\hline \multirow{4}{*}{$50 \mathrm{~m}$} & $10-10$ & 35.36 & 35.17 & 85.8 & 86.3 & 10.53 & 10.39 & 4.18 & 4.17 \\
\cline { 2 - 10 } & $15-15$ & 35.24 & 35.60 & 86.3 & 86.4 & 10.54 & 10.48 & 4.19 & 4.21 \\
\cline { 2 - 9 } & $20-20$ & 35.35 & 35.39 & 86.3 & 86.6 & 10.63 & 10.49 & 4.12 & 4.22 \\
\hline \multicolumn{2}{|c|}{ LSD at 0.05} & N.S. & N.S. & N.S. & N.S. & N.S. & N.S. & N.S. & N.S. \\
\hline
\end{tabular}

\section{CONCLUSION}

The results revealed that using $30 \mathrm{~m}$ row length irrigation and surge irrigation timing systems (10-10) (10 minutes open and 10 minutes close) gave the highest seed cotton yield/fed. for Giza 96 cotton cultivar under the conditions of Kafr ElSheikh location in the Delta soils.

\section{REFERENCES}

A.S.T.M. (2012). American Society Testing and Materials. D4605, 7(1), Easton, MD, USA.

Aujla, M.S., H.S. Thind and G.S. Butter (2004). Cotton yield and water use efficiency at various levels of water and $\mathbf{N}$ through drip irrigation under two methods of planting. Agric. Water Manag. 71: 167-179.

Bange, M.P. and S.P. Milroy (2000). Timing of crop maturity in cotton impact of dry matter production and partitioning. Field Crops Res. 68: 143 $-155$.

Bonner, C.M. (1993). Management of cotton for early maturity. Cotton comments, Ark. Coop. Ext. Serv., Little Rock, AR, 2 - 93.

Buttar, G.S., M.S. Aujla, H.S. Thind, C.J. Singh and K.S. Saini (2007). Effect of timing of first and last irrigation on the yield and water use efficiency in cotton. Agric. Water Manage. 89: 236 242.

Chun-yan, W., L. Mao-song and W. Daolong (2007). Growth and ecophysiological performance of cotton under water stress conditions. Agric. Sci. China. 6(8): 949 - 955.

Deshish, El-D. El-D., S.A.F. Hamoda and M.A.A. Emara (2015 a). Study of new irrigation systems under planting dates to increasing productivity of cotton. Egypt . J. of Appl. Sci., 30 (12): 564-573

Deshish, El-D. EI-D., S.A.F. Hamoda and M.A.A. Ibrahim (2015b). Cotton response to planting distance and different surface irrigation systems in heavy soil at North Delta. Alex. Cotton Conf. (25-26 March 2015). Special Issue of J. Adv. Agric. Res., Fac. of Agric., Saba Basha: 86-97. 
Detar, W.R. (2008). Yield and growth characteristics for cotton under various irrigation regimes on sandy soil. Agric. Water Manage, 95: 69 - 76.

Ertek, A. and R. Kanber (2003). Effects of different drip irrigation programs on the boll number and shedding percentage and yield of cotton. Agric. Water Manage. 60: 1 - 11.

Freed, R.D. (1991). M Stat-C Microcomputer Statistical Program. Michigan State Univ., first Lansing, Michigan, USA.

Jalota, S., A. Sood, G. Chahal and B. Choudhury (2006). Crop water productivity of cotton (Gossypium hirsutum L.) wheat (Triticum aestivum L.) system as influenced by deficit irrigation, soil texture and precipitation. Agric. Water Manag. 84 (1-2): 137 - 146.

Karam, F., L. Rafic, M. Randa, A. Daccache, $O$. Mounzer and Y. Rouphael (2006). Water use and lint yield response of drip-irrigated cotton to length of season. Agric. Water Manage, 85: 287 - 295.

Khalifa, EL-S.M.A., EL-D. EL-D. Deshish and S.A.F. Hamoda (2014). Effect of irrigation methods at different soil moisture depletion levels on growth and productivity for new promising hybrid cotton [Giza 84 (Giza 70 x 51B)] Pima 62 Egypt. J. Agric. Res., 92 (1): 153-165
Mert, M. (2005). Irrigation of cotton cultivars improves seed cotton yield, yield components and fibre properties in the Hatay region, Turkey. Acta Agriculturae Scandinavica. Section B, Soil Plant, 55: 44 - 50.

Morrow, M.R. and D.R. Krieg (1990). Cotton management strategies for a short growing season environment: water-nitrogen considerations. Agron, J. 82: $52-56$.

Sezan, S., A. Yazar, A. Akyildiz, H. Dasgan and B. Gencel (2008). Yield and quality response of drip irrigated green beans under full and deficit irrigation. Sci. Hort., 117: 95 - 102.

Snedecor and Cochran (1989). Statistical Methods. $7^{\text {th }}$ Ed. Press, lowa, Ames, pp: $225-269$.

Steger, A.J., J.C. Silvertooth and P.W. Brown (1998). Upland cotton growth and yield response to timing the initial postplant irrigation. Agron. J., 90: 455 $-461$.

Tekinel, O. and R. Kanber (1989). The general rules of cotton irrigation. University of Cukurova, Agricultural Faculty Publication, No:18. Adana, Turkey. p. 56.

Turner, N.C., A.B. Hearn, J.E. Begg and G.A. Constable (1986). Cotton (Gossypium hisutum L): physiological and morphological responses to water deficits and their relationship to yield. Field Crops Res., 14: 153-170. 
زيادة كفاءة الرى السطحى باستخدام الرى النبضى لانتاج القطن فى ارض الالتا

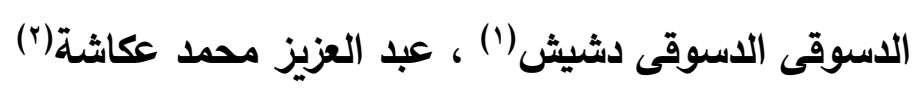

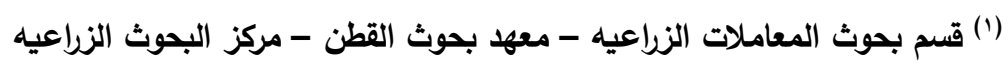

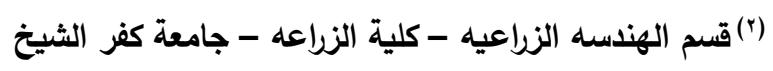

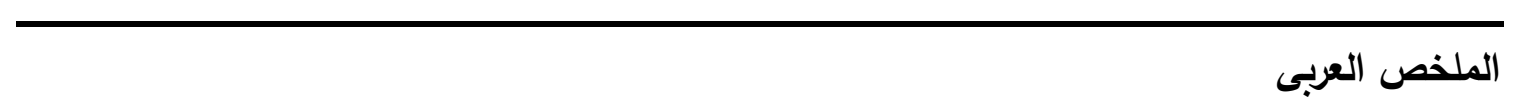

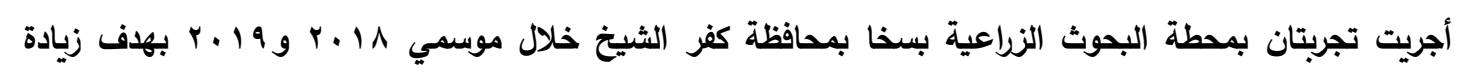

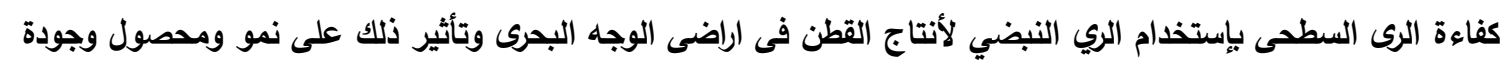

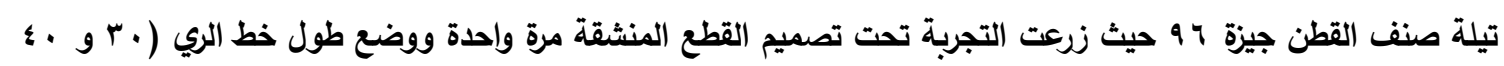

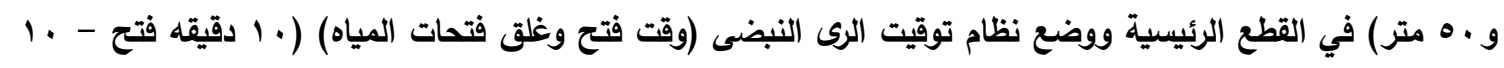

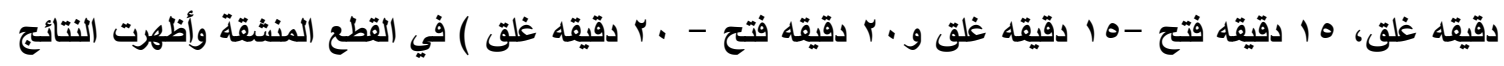

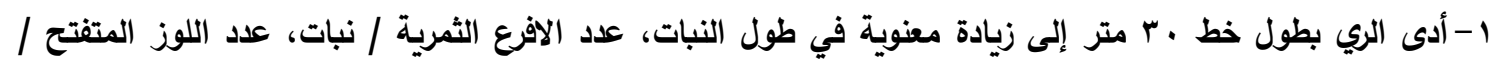

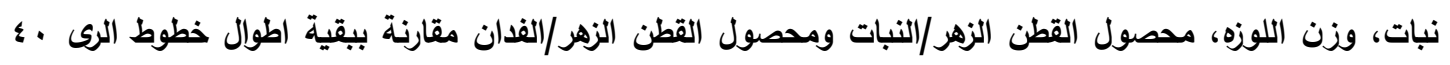

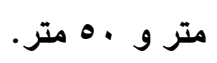

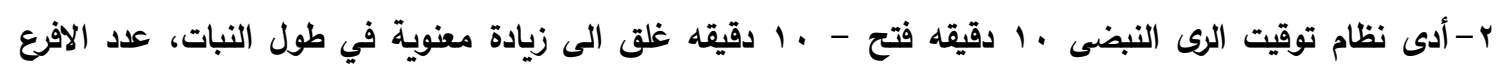

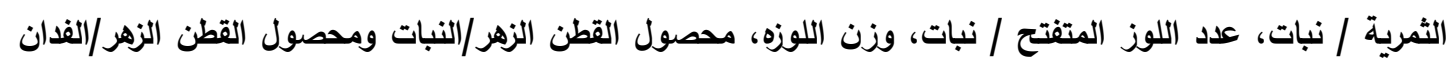

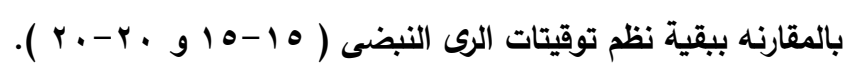

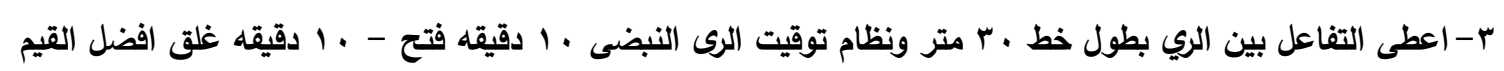

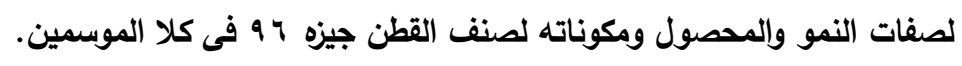

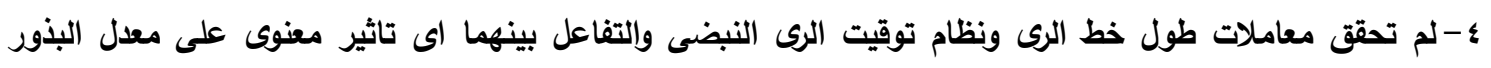
وتصافى الحليج وصفات التيلة فى كلا الموسمين.

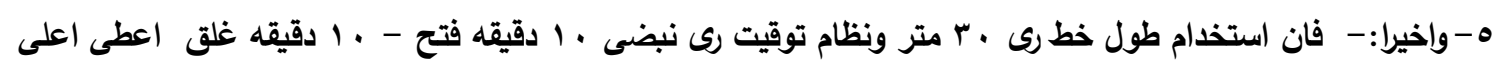

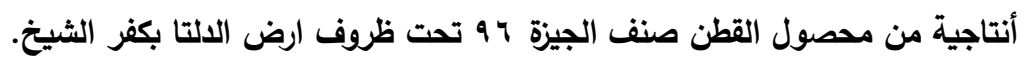

أسماء السادة المحكمين أ.د/ مصطفى عطيه أحمد عماره معهد بحوث القطن - قسم المعاملات الززراعية بالجيزة أ.د/ محمود الاسوقى إبراهيم علية الززاعة - جامعة المنوفية 